\title{
Comparison of Clinical Laboratory Data and Prevalence according to Arterial Stiffness in Stroke Patients
}

\author{
Bok Hee Jin ${ }^{1}$ and Min Ho Han ${ }^{2}$ \\ ${ }^{1}$ Department of Clinical Laboratory Science, Wonkwang Health Science University, Iksan 570-750, Korea, \\ ${ }^{2}$ Department of Neurology, Yonsei University Severance Hospital, Seoul 120-752, Korea
}

\begin{abstract}
Pulse wave velocity (PWV) is used to non-invasively estimate the severity of arteriosclerosis by measuring the patient's arterial stiffness comparing with each normal reference range according to their ages. Increased arterial stiffness is closely related to both atherosclerosis and arteriosclerosis, which have been known for causes of cardiovascular disease and stroke, also negatively affects the prognosis and the re-occurrence in patients with stroke. The study is focused on how brachial-ankle pulse wave velocity (baPWV) is related to cardiovascular disease risk factors in patients with acute stroke. There were 114 subjects, 69 males and 45 females, all in their 60's and had PWV test for acute stroke. The results are as follows: the group with increased arterial stiffness showed significant increase in HbAlc, total cholesterol, RSBP (resting systolic blood pressure), CSBP (central systolic blood pressure) and CDBP (central diastolic blood pressure). Cross tabulation test showed that there was a significant relationship only between the group with increased arterial stiffness and diabetes mellitus (DM). Therefore, it might be useful for preventing re-occurrence and making a favorable prognosis to promptly adjust DM and hypertension-related risk factors in patients with acute stroke.
\end{abstract}

Keywords: Stroke, Brachial-ankle pulse wave velocity, Arterial stiffness

This is an Open Access article distributed under the terms of the Creative Commons Attribution Non-Commercial License (http://creativecommons.org/licenses/by-nc/3.0) which permits unrestricted non-commercial use, distribution, and reproduction in any medium, provided the original work is properly cited.

Copyright ( 2014 The Korean Society for Clinical Laboratory Science. All rights reserved.
Corresponding author: Min $\mathrm{Ho} \mathrm{Han}$ Department of Neurology, Yonsei University Severance Hospital, Seoul 120-752, Korea Tel: 82-2-2228-5283

E-mail: umsthol18@gmail.com

Received: October 16, 2014 Revised: December 23, 2014 Accepted: December 25, 2014

\section{서 론}

뇌졸중 환자에서 동맥경직도(arterial stiffness)의 증가는 뇌졸 중의 위험도를 증가시키는 것으로 알려져 있다(Choi 등, 2009). 동 맥경화증(arteriosclerosis)이 있는 경우 동맥은 탄성도가 감소되 어 있고, 그에 반해 동맥경직도는 증가되어 있는데, 이들 환자에서 동맥의 맥파전파속도(pulse wave velocity, PWV)와 맥압(pulse pressure)은 상대적으로 크게 상승되어 있다(McLeod 등, 2004). 따라서 PWV는 심장혈관계통 질환 사망률의 독립적인 예측인자로 (Izzo, 2004), 동맥경화에 의한 혈관사고(vascular event)의 위험 도를 평가하는데 중요한 예측인자이다(Blacher 등, 1999). 단단해 진 중심동맥의 경우, 혈압에 대한 완충작용을 제대로 수행하지 못 하기 때문에 수축기 혈압을 더욱 상승시키게 되고, 이에 반해 이완 기 되튐(recoil)은 더욱 감소시킨다. 이는 수축기 혈압과 이완기 혈 압의 차이를 더욱 증가시킴으로서 맥압은 상승되고, 좌심실로부터 대동맥으로 구출되는 혈류량은 단단해져 있는 대동맥으로 부터 큰
저항을 받아 좌심실 구출률(ejection fraction)은 감소하게 된다. 결국 감소된 구출률을 증가시키기 위해 좌심실의 근육은 더 많은 노력을 하게 되고, 이러한 현상이 지속될 경우 좌심실에 큰 부하가 걸려 좌심실비대(left ventricular hypertrophy)가 될 수 있다. 또한 이완기 혈압의 감소는 심장동맥의 관류압을 감소시켜 심내막하허혈 (subendocardial ischemia)과 심근경색증(myocardial infarction) 을 일으킬 수 있다(조 등, 2006).

따라서 동맥경직도의 지표가 되는 PWV는 뇌졸중 및 심장혈관 계통 질환의 증상이 발생하기 전에 동맥의 변화를 초기에 진단하기 위한 검사로 비교적 간단하게 반복적으로 측정할 수 있고 비침습적 이기 때문에 임상에서 많이 측정되고 있다. 또한 이미 뇌졸중이 발 생한 환자에서 어느 정도 예후를 관찰 할 수 있고, 보다 적합한 치료 를 선택하는데도 도움이 될 수 있다(Seo 등, 2008; Kim 등, 2011). 하지만, 기존에 많은 연구들을 통해 고혈압, 저밀도지단백콜레스 테롤, 당뇨, 심장질환 등이 뇌졸중을 일으키는 주요 위험인자로서 밝혀졌지만, 이미 뇌졸중이 발생한 환자를 대상으로 고전적 심장혈 
관계통 질환 위험인자들과 PWV 간의 상관관계를 분석한 연구는 비교적 많지 않고, 본 연구에서는 기존 연구방법들과는 달리 $\mathrm{baPWV}$ 의 결과지에서 제시되는 검사 결과를 바탕으로 대상자를 정상군과 비정상군으로 분류하여 위험인자들 간의 상관성을 분석 하였기 때문에 보다 흥미로운 결과를 유도할 수 있을 것이라 생각 된다. 따라서 본 연구에서는 동맥경직도에 따른 임상검사 결과와 유병률을 비교하여 동맥경직도와 뇌졸중 위험인자와의 관련성에 대해 알아보고자 하였다.

\section{재료 및 방법}

\section{1. 대상}

본 연구는 후향성 단면 연구로서 2012년 6월부터 2013년 3월까 지 급성 허혈성 뇌경색(acute ischemic brain infarction)이나 일 과성 허혈 발작(transient ischemic attack)이 발생하여 증상 발현 후 7일 이내에 A병원에 입원한 환자를 대상으로 총 114 명이 연구 에 참여하였다. 모든 대상자는 병력 및 흡연력이 조사되었으며, 혈 액검사와 함께 위팔-발목 맥파전파속도(brachial-ankle pulse wave velocity, baPWV)와 목동맥-넙다리동맥 맥파전파속도 (carotid-femoral pulse wave velocity, cfPWV)를 측정하였다. 환자의 협조가 이루어지지 않아 두 맥파전파속도 검사 중 하나만 시
행했거나, 부정맥(arrhythmia), 말초폐쇄성동맥질환(peripheral arterial occlusive disease, PAOD), 발목-위팔 동맥압 지수 (ankle-brachial index, ABI)가 0.9 미만인 경우에는 대상자 선정 에서 제외되었다. 두 맥파전파속도 측정시 부정맥 환자의 불규칙한 맥파로 인해 검사측정이 어렵고 측정되어도 검사결과가 부정확하 다(Kim 등, 2011). 또한 PAOD가 있거나 <0.9 ABI를 보이는 환자 는 말초혈관의 심한 폐색으로 인해 동맥의 경직도와상관없이 다양 한 속도의 혈류를 야기할 수 있으므로 검사 결과의 신뢰성이 떨어 질 우려가 있기 때문이다(Motobe 등, 2005).

\section{2. 위팔-발목 맥파전파속도(baPWV)의 측정}

모든 대상자는 누운 자세에서 최소 5 분 정도 안정시킨 후자동 파 형분석기(VP-1000, Colin Co, Komaki, Japan)를 사용하여 $\mathrm{baPWV}$ 를 측정하였다. baPWV는 자동 파형분석기의 oscillometric sensor가 장착된 4 개의 cuff를 양쪽 위팔동맥과 뒤정강동맥에 감 고 동시에 동맥의 혈압과 맥파를 기록하였다. 양쪽 손목에 심전도 유도를 부착하여 심전도를 감시하였고, 흥골 좌측 가장자리의 제 2 늑간에 심음도 microphone을 부착하였다(Fig. 1). PWV를 결정하 는데 필요한 시간간격 $(\triangle \mathrm{T})$ 은 오른쪽 팔과 양쪽 다리에서 기록된 맥파를 통해 얻어지게 되며(Fig. 2), 측정 지점 간의 거리(L)는 환자 의 신장을 이용하여 모두 파형분석기에서 자동적으로 계산되었다.
A

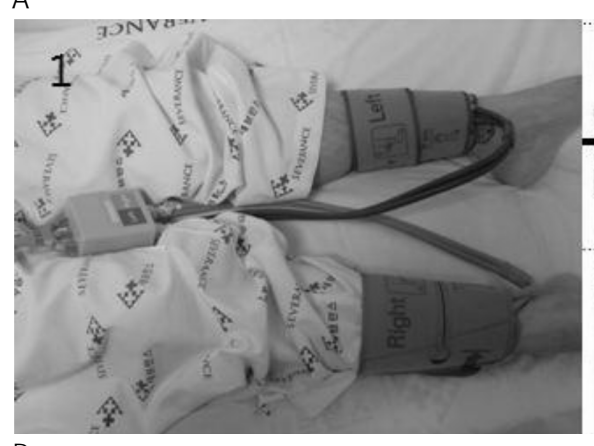

D

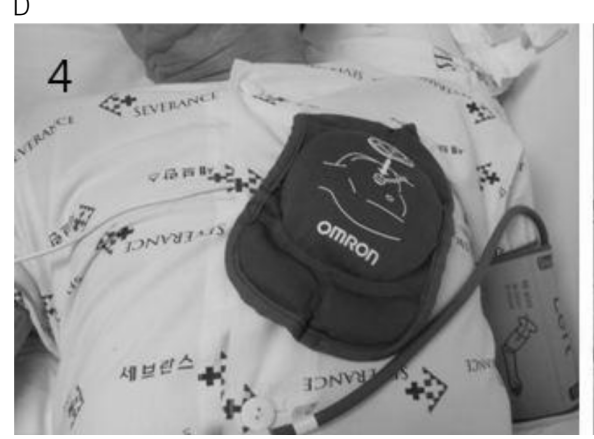

B
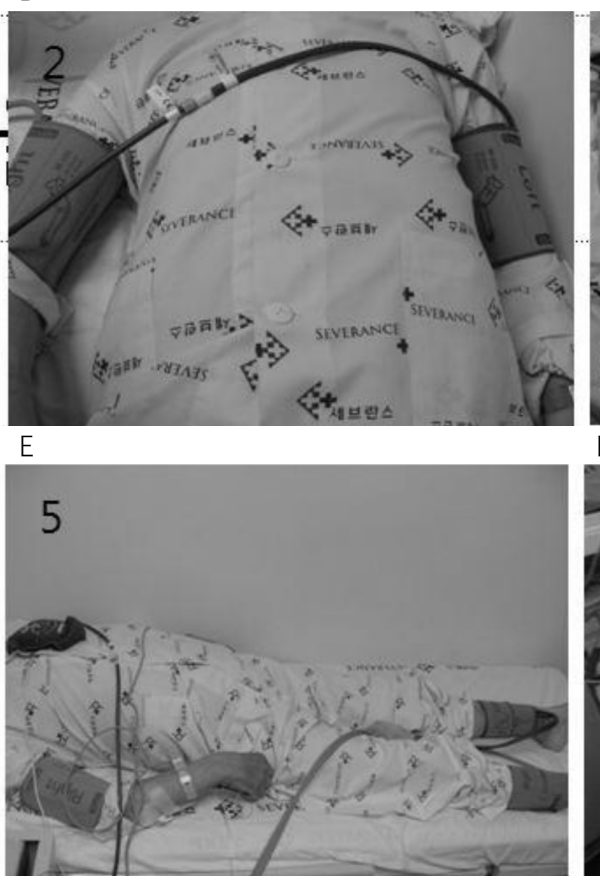

C

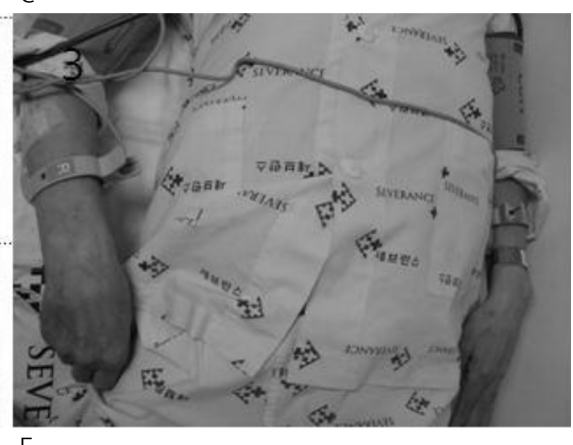

$\mathrm{F}$

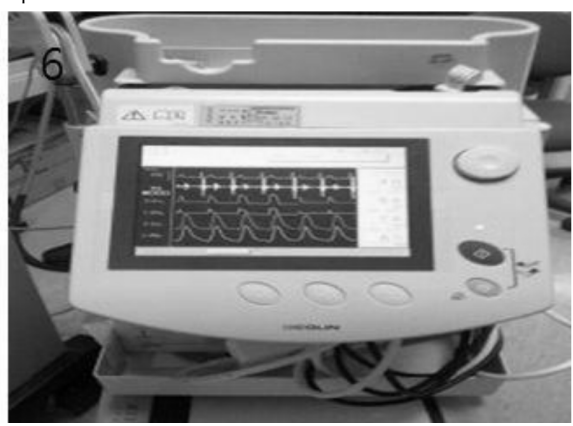

Fig. 1. Flowchart showing baPWV measurement according to the order. (A) Ankle cuffs were wrapped. (B) Arm cuffs were wrapped. (C) ECG electrodes were placed on both wrists. (D) Heart sound microphone was placed on the left sternal border. (E) A scene of a patient with all the sensors attached. (F) Pulse volume record (PVR) was recorded. 
각 편측의 $\mathrm{baPWV}$ 는 시간간격 $(\triangle \mathrm{T})$ 을 측정 지점 간의 거리 $(\mathrm{L})$ 로 나 누어 얻을 수 있고, 본 연구에 이용된 baPWV는 양측 $\mathrm{baPWV}$ 의 수 치를 평균화하여 얻어진 값이다. 또한 동맥경직도에 따른 임상검사

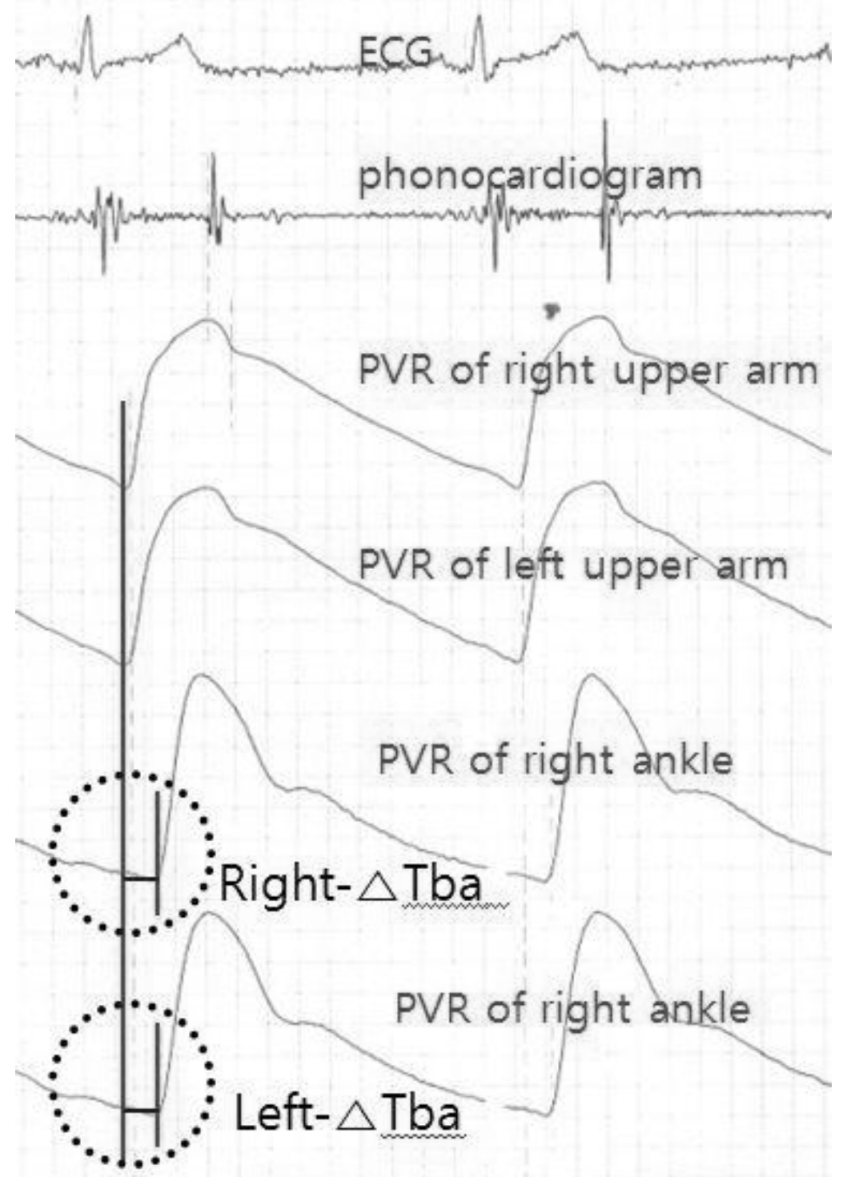

Fig. 2. The transmission time obtained by PVR.
결과와 유병률을 비교하기 위해 맥파전파속도 장비에서 측정된 동 맥경직도를 바탕으로 대상자의 baPWV가 연령에 비해 낮으면 (with in normal) 정상군으로, 약간 높거나(slightly hard), 많이 높 으면(harder) 비정상군으로 분류하여 연구를 진행하였다. 이러한 두 군의 세부적인 판단 기준은 결과지의 X축을 연령으로, $\mathrm{Y}$ 축을 $\mathrm{PWV}$ 로 하는 그래프에서 정상범위 안에 대상자의 baPWV값이 위 치할 경우는 정상군(normal group or with in normal)으로 정의 되며, 그 외의 양측 $\mathrm{baPWV}$ 값 중에서 어느 한쪽이라도 정상범위를 상향하여 벗어날 경우에는 비정상군(abnormal group or slightly hard+harder)으로 정의되었다(Fig. 3).

\section{3. 목동맥-넙다리동맥 맥파전파속도(cfPWV)의 측정}

$\mathrm{baPWV}$ 와 cfPWV 모두 속도(velocity)를 측정하는 것이므로 시 간간격 $(\triangle \mathrm{T})$ 을 측정 지점 간의 거리 $(\mathrm{L})$ 로 나누어 값을 얻는 측정원 리는 같으며, 다만 측정부위와 측정장비에는 차이가 있다. 모든 대 상자는 누운자세에서 최소 5 분 정도 안정시킨 후 전자식자동 혈압계 를 이용하여 $\mathrm{PAOD}$ 가 없는 쪽의 위팔동맥에서 혈압을 측정하였고, 자 동 파형분석기(SphygmoCor, AtCor Medical, NSW, Australia)의 tonometric sensor가 장착된 probe를 이용하여 직접 편측 목동맥 의 맥파를 측정한 후 동측 넙다리동맥의 맥파를 연속적으로 기록하 였다. 또한 동시에 양쪽 손목과 왼쪽 다리에 심전도 유도를 부착하 여 심전도를 관찰하였다. 시간간격 $(\triangle \mathrm{T})$ 은 목동맥과 넙다리동맥에 서 기록된 맥파를 통해 얻어졌다. 측정 지점 간의 거리(L)는 직접 줄 자를 이용하여 체표면 위에서 목동맥으로부터 복장패임(흉골절흔, sternal noch)까지의 거리(1구간)를 측정하고 복장패임으로부터 넙다리동맥까지의 거리(2구간)를 측정하여, 2 구간의 거리에서 1 구간의 거리를 빼주어 얻었다.

\section{$\triangle \mathrm{R}: 1279 D_{\mathrm{L}:} 1279$}

(Prevalue R: --- L: ---)

Compared to the healthy men of the age 56 ,

\section{it is within normal range.}

baPWV mainly measures the large arterial stiffness and it does not indicate the cerebrovascular

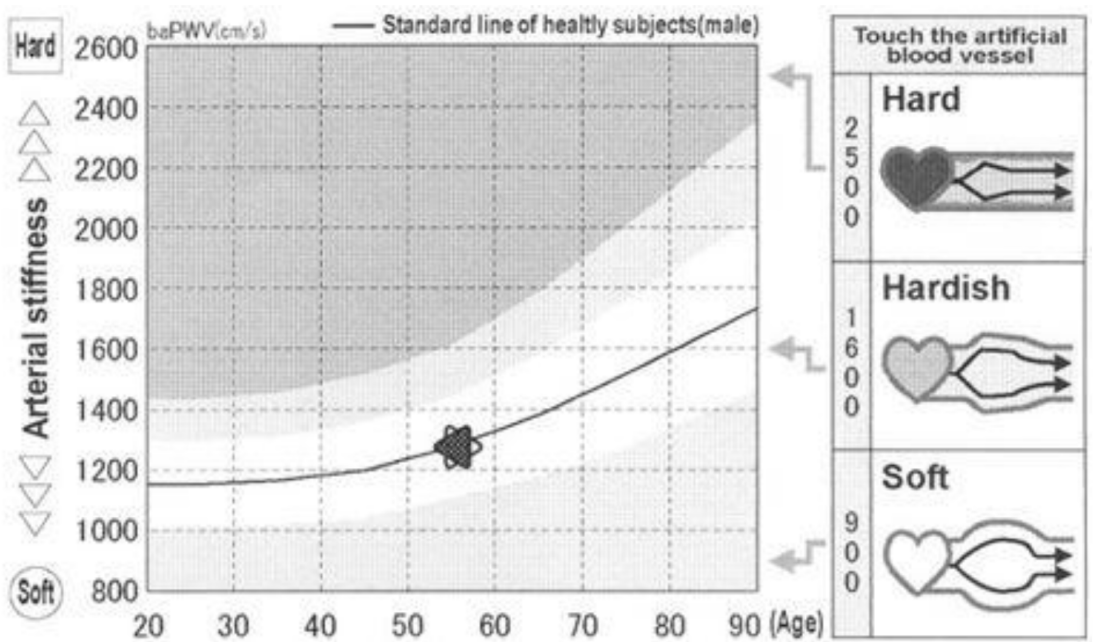

Fig. 3. The baPWV finding categorized based on the xy-plane on the result tables. 


\section{4. 뇌졸중 위험인자}

고혈압은 진단받았거나, 안정 시 반복 측정에서 위팔동맥의 수 축기 혈압이 $\geq 140 \mathrm{mmHg}$ 또는 이완기 혈압이 $\geq 90 \mathrm{mmHg}$ 인 경 우이다(Jones 등, 2004). 당뇨는 공복혈당이 $\geq 7.0 \mathrm{mmol} / \mathrm{L}$ 또는 약이나 인슐린 치료를 받고 있는 경우이다(Expert Committee on the Diagnosis and Classification of Diabetes Mellitus, 2003). 고콜레스테롤혈증은 고콜레스테롤혈증을 진단받았거나, 저밀도 지단백콜레스테롤이 $\geq 4.1 \mathrm{mmol} / \mathrm{L}$ 또는, 총콜레스테롤이 $\geq 6.2$ $\mathrm{mmol} / \mathrm{L}$ 인 경우이다(Expert Panel on Detection, Evaluation, and Treatment of High Blood Cholesterol in Adults, 2001). 현 재 흡연은 입원 전까지 흡연을 하고 있는 경우이다. 체질량지수 (body mass index, BMI)는 $\mathrm{kg}$ 단위의 몸무게를 $\mathrm{m}$ 단위의 신장의 제곱으로 나누어 산출하였다. 심장동맥질환은 불안정 협심증이나 심장동맥 폐쇄성 질환 또는 심근경색이 있는 경우이다. 안정 시 위 팔동맥의 수축기 혈압(resting brachial artery systolic blood pressure, RSBP)과 이완기 혈압(resting brachial artery diastolic blood pressure, $\mathrm{RDBP}$ )은 입원 48시간 이후 신경학적으로 안정한 상태에서 측정된 혈압이다. 중심동맥의 수축기 혈압(central artery systolic blood pressure, CSBP)과 이완기 혈압(central artery diastolic blood pressure, $\mathrm{CDBP}$ )은 (fPWV와 동일한 장비 로 측정된 노동맥 파형을 일반적인 전달 공식(generalized transfer function)을 이용하여 중심동맥의 파형을 구한 후 분석하 였다. 허리둘레(waist)는 바로 누운 자세에서 배꼽부위를 줄자로 측정하였다.

\section{5. 통계분석}

대상자의 임상 특성은 기술통계분석을 통해 범주형 변수에 대해 서는 관측빈도 $(\%)$ 로 기술하였으며, 연속형 변수에 대해서는 평균 \pm 표준편차(최소값 최대값)로 표현하였다. baPWV 결과에 따른 정상군과 비정상군 간의 뇌졸중 위험인자의 통계적 차이를 확인하 기 위해서는 독립 T검정(independent T-test) 분석을 실시하였다. 동맥경직도에 따른 두 군간의 뇌졸중 관련 질환의 유병률을 비교하
기 위해서 교차분석을 실시하였으며, 단 분할표에서 cell의 기대빈 도가 5 이하인 경우가 전체 $20 \%$ 를 넘는 경우에는 Fisher's exact test를 실시하여 얻어진 $p$ value를 사용하였다.

모든 통계분석은 SPSS Win (ver 12.0)을 이용하였으며, 모든 측 정치에 대해서 범주형 변수는 관측빈도(\%)로 표현하였으며, 연속 형 변수는 평균 \pm 표준편차로 표현하였다. 그리고 유의미한 수준은 0.05 미만 $(p<0.05)$ 으로 하였다.

\section{결 과}

\section{1. 대상자의 특성}

급성 허혈성 뇌경색이나 일과성 허혈 발작이 발생하여 증상 발 현 후 7일 이내에 입원한 환자 171명 중 협조가 되지 않아 두 PWV 중 하나만 측정한 24명, 부정맥이 있는 25 명, PAOD가 있는 2명, $\mathrm{ABI}<0.90$ 인 6 명을 제외한 114 명이 최종 연구에 포함되었다. 연구 대상자의 평균 연령은 $62.03 \pm 10.88$ 세이었고, $\mathrm{BMI}$ 는 $24.04 \pm 3.06$ $\mathrm{kg} / \mathrm{m}^{2}$ 이였으며, 허리둘레는 $86.54 \pm 8.70 \mathrm{~cm}$ 이었다. $\mathrm{baPWV}$ 는 $19.15 \pm 4.89 \mathrm{~m} / \mathrm{sec}$ 이었고, $\mathrm{cfPWV}$ 는 $9.83 \pm 2.80 \mathrm{~m} / \mathrm{sec}$ 으로 $\mathrm{baPWV}$ 보다 상대적으로 높았다(Table 1).

\section{2. 동맥경직도에 따른 임상검사 결과의 비교}

혈당(blood sugar)은 두 군 간에 유의미한 차이는 없었으나 ( $p=0.485)$ 당화혈색소(HbAlc)는 비정상군에서 유의미하게 증가 되었다 $(p=0.032)$.

총콜레스테롤(total cholesterol)은 비정상군에서 유의미하게 증가되었다 $(p=0.046)$. 하지만, 중성지방(triglyceride), 고밀도지 단백콜레스테롤(HDL cholesterol), 저밀도지단백콜레스테롤(LDL cholesterol)은 비정상군에서 증가되는 경향을 보였으나 두 군 간 에 유의미한 차이는 없었다 $(p>0.05)$.

$\operatorname{RDBP}(p=0.275)$ 를 제외한 모든 혈압과 관련된 $\operatorname{RSBP}(p=0.049)$, $\operatorname{CSBP}(p=0.007), \operatorname{CDBP}(p=0.001)$ 은 비정상군에서 통계적으로 유의미하게 증가되었다(Table 2).

Table 1. Clinical characteristics of study subjects

\begin{tabular}{lccc}
\hline \multicolumn{1}{c}{ Variables } & Normal group (with in normal) & Abnormal group (slightly hard+harder) & Total \\
\hline Gender $(\mathrm{M} / \mathrm{F})$ & $10(76.9 \%) / 3(23.1 \%)$ & $59(58.4 \%) / 42(41.6 \%)$ & $69(60.5 \%) / 45(39.5 \%)$ \\
Age $(\mathrm{yrs})$ & $62.50 \pm 9.86(36 \sim 73)$ & $61.97 \pm 11.04(34 \sim 81)$ & $62.03 \pm 10.88(34 \sim 81)$ \\
BMI $\left(\mathrm{kg} / \mathrm{m}^{2}\right)$ & $23.70 \pm 2.23(19.72 \sim 26.53)$ & $24.08 \pm 3.15(16.41 \sim 33.30)$ & $24.04 \pm 3.06(16.41 \sim 33.30)$ \\
Waist $(\mathrm{cm})$ & $84.50 \pm 8.17(74 \sim 95)$ & $86.78 \pm 8.76(66 \sim 113)$ & $86.54 \pm 8.70(66 \sim 113)$ \\
baPWV $(\mathrm{m} / \mathrm{sec})$ & $14.28 \pm 1.53(11.8 \sim 16.3)$ & $19.73 \pm 4.83(12.6 \sim 34.0)$ & $19.15 \pm 4.89(11.8 \sim 34.0)$ \\
cfPWV $(\mathrm{m} / \mathrm{sec})$ & $8.03 \pm 1.56(6.2 \sim 11.2)$ & $10.04 \pm 2.85(4.8 \sim 21.87)$ & $9.83 \pm 2.80(4.8 \sim 21.87)$ \\
\hline
\end{tabular}

BMI (body mass index)=weight $(\mathrm{kg}) /[\text { height }(\mathrm{m})]^{2}$. baPWV, brachial-ankle pulse wave velocity; cfPWV, carotid-femoral pulse wave velocity. 
Table 2. Comparison of clinical laboratory data according to arterial stiffness

\begin{tabular}{lccc}
\hline \multicolumn{1}{c}{ Variables } & Normal group (with in normal) & Abnormal group (slightly hard+harder) & $p$ value \\
\hline Blood sugar $(\mathrm{mg} / \mathrm{dl})$ & $133.77 \pm 30.32$ & $145.78 \pm 60.73$ & 0.485 \\
HbAlc $(\mathrm{mg} / \mathrm{dl})$ & $6.18 \pm 0.46$ & $6.61 \pm 1.24$ & 0.032 \\
Total cholesterol $(\mathrm{mg} / \mathrm{dl})$ & $154.49 \pm 61.48$ & $179.30 \pm 38.69$ & 0.046 \\
Triglyceride $(\mathrm{mg} / \mathrm{dl})$ & $108.45 \pm 54.68$ & $133.11 \pm 80.21$ & 0.323 \\
HDL cholesterol (mg/dl) & $41.83 \pm 6.85$ & $43.53 \pm 13.21$ & 0.662 \\
LDL cholesterol (mg/dl) & $100.58 \pm 29.69$ & $100.78 \pm 31.74$ & 0.984 \\
RSBP (mmHg) & $125.92 \pm 11.38$ & $136.61 \pm 18.11$ & 0.049 \\
RDBP (mmHg) & $77.75 \pm 10.26$ & $81.77 \pm 12.78$ & 0.275 \\
CSBP (mmHg) & $114.46 \pm 18.32$ & $130.63 \pm 19.98$ & 0.007 \\
CDBP (mmHg) & $72.77 \pm 8.67$ & $84.59 \pm 12.02$ & 0.001 \\
\hline RSBP, resting
\end{tabular}

RSBP, resting systolic blood pressure; RDBP, resting diastolic blood pressure; CSBP, central systolic blood pressure; CDBP, central diastolic blood pressure; HbAlc, Hemoglobin Alc.

Table 3. Comparison of prevalence according to arterial stiffness

\begin{tabular}{lcrc}
\hline \multicolumn{1}{c}{ Variables } & Normal group (with in normal) & Abnormal group (slightly hard+harder) & $p$ value \\
\hline Diabetes mellitus (\%) & $1(2.4)$ & $41(97.6)$ & 0.029 \\
Hypercholesterolemia (\%) & $1(5.9)$ & $16(94.1)$ & 0.688 \\
Hypertension (\%) & $6(8.3)$ & $66(91.7)$ & 0.225 \\
Smoking (\%) & $3(10.7)$ & $25(89.3)$ & 1.000 \\
Coronary artery disease (\%) & $3(7.7)$ & $36(92.3)$ & 0.537 \\
\hline
\end{tabular}

\section{3. 동맥경직도에 따른 뇌졸중 관련 질환 유병률의 비교}

당뇨병(diabetes mellitus, DM)은 비정상군에서 통계적으로 유 의미하게 증가되었다( $p=0.029)$. 고콜레스테롤혈증(hypercholesterolemia), 고혈압(hypertension), 흡연(smoking), 심장동맥질 환(coronary artery disease, $\mathrm{CAD}$ )은 비정상군에서 증가되는 경 향을 보였으나 두 군간에 유의미한 차이는 없었다 $(p>0.05)$ (Table 3).

\section{고 찰}

PWV는 뇌졸중(stroke)과 심장혈관계통 질환(cardiovascular disease)의 독립적 위험요소인 동맥경직도를 측정할 수 있는 유용 한 검사이다(Laurent 등, 2003). 또한 증가된 PWV는 동맥경화가 진행되고 있음을 보여주는 지표가 되며, 동맥경화의 진행은 뇌졸중 이나 심장혈관계통 질환의 원인이 될 수 있는 독립적인 위험인자이 므로 PWV의 측정은 혈관질환의 예방 및 예후를 파악하는데 도움 이 된다(Boutouyrie 등, 2002; McLeod 등 2004). 본 연구는 급성 뇌졸중 환자에서 측정된 baPWV의 결과를 바탕으로 대상자를 동 맥경직도가 정상인 군과 동맥경직도가 높은 군으로 나누어, 두 군 간의 뇌졸중 위험인자로 잘 알려진 임상 검사 항목들과 뇌졸중 관 련 질환들의 유병률에 차이가 있는지를 비교하였다.
박 등(2005)은 60세 이상의 연령에서 당뇨가 있는 경우 PWV를 증가시키는 동맥경직도의 증가는 심장동맥질환을 증가시키는 유 의한 위험인자라고 보고하였다. 기존의 연구결과와 비교해 볼 때, 본 연구에서도 동맥경직도가 높은 군에서 통계적으로 유의미한 수 준은 아니지만 혈당치가 증가되는 경향을 보였고, 또한 당화혈색소 와 당뇨병 유병률의 비교에서 뚜렷이 증가된 결과를 보여 일치된 소견을 보였다. 또한, 60세 이상의 연령에서 고지혈증이 있는 경우 $\mathrm{PWV}$ 를 증가시키는 동맥경직도의 증가는 심장동맥질환을 증가시 키는 유의한 위험인자라고 보고하였으며, 고지혈증은 대동맥의 $\mathrm{PWV}$ 를 증가시키는 원인이 될 수 있고, 다른 심장혈관계통 질환 위 험인자를 모두 포함한 다변량 분석에서도 대동맥의 PWV를 증가시 키는 유의한 독립적 위험인자라고 보고하였다. 본 연구에서도 기존 의 연구결과와 마찬가지로 연령에 비해 동맥경직도가 높은 군에서 총콜레스테롤이 유의미하게 증가되었다. 그러나 나머지 혈액 중 지질 성분에 포함되는 triglyceride, HDL cholesterol, LDL cholesterol 에서는 동맥경직도가 높은 군에서 통계적으로 유의미한 증가나 감 소를 볼수 없었고, 고콜레스테롤혈증에 대한 유병률에서도 유의미 한차이를 볼 수 없었다. 이러한 결과는 본 연구 대상자의 수가 상대 적으로 기존 연구들의 규모에 비해 적었기 때문에 총콜레스테롤을 제외한 나머지 변수에서 빈도수나 수치가 높았음에도 불구하고, 유 의미한 결과를 얻기 어려웠다고 생각된다.

동맥경직도는 수축기 동맥압과 맥압의 증가를 결정하는 중요한 
인자이다(Laurent와 Boutouyrie, 2007). 본 연구에서도 연령에 비 해 동맥경직도가 높은 군에서 $\mathrm{RDBP}$ 를 제외한 RSBP, $\mathrm{CSBP}, \mathrm{CDBP}$ 모두에서 유의미한 증가가 되었으며, 통계적으로 유의하지는 않았 으나 고혈압 유병률에서도 높은 경향을 보였다. 이와 같은 결과는 박 등(2005)이 고혈압이 있는 경우 대동맥 PWV는 유의하게 높았 으며, 고혈압을 포함한 다변량 분석에서도 그 유의성은 유지되었다 는 결과와 어느 정도 부합하는 소견으로 생각된다. 고혈압 등에 의 해서 동맥이 경화되면 동맥경직도의 증가에 의해 수축기 혈압은 증 가되고, 이완기 혈압은 감소되어, 결국 맥압은 더욱 증가하게 된다 (Zieman 등, 2005; Hamilton 등, 2011). 또한, 동맥경화에 의해 상 승된 혈관 저항으로 좌심실 구출률의 감소와 심장의 후부하(after load)가 증가되고, 동시에 이완기 혈압은 감소되어 심장동맥을 통 한 심장으로 혈류 공급이 원활히 진행되지 못하여 심장동맥질환의 발생 위험을 더욱 증가시킨다(Franklin 등, 1999).

흡연(smoking)은 심장혈관질환의 위험을 상승시키는 인자 중 하나로 일시적으로 맥박수와 혈압을 상승시켜 동맥경직도를 증가 시킬 수 있으나 PWV를 통한 동맥경직도와 만성 흡연 간에 유의한 상관성을 관찰하고자 한 선행 연구에서 통계적으로 유의미한 관계 를 관찰할 수는 없었다(Rhee, 2005). 본 연구에서도 연령에 비해 동맥경직도가 높은 군에서 흡연율이 높은 경향을 보였으나, 통계적 으로 유의미한 관계는 관찰되지 않았다.

본 연구는 뇌졸중이나 심장혈관질환이 있는 비정상군과 정상 대 조군 간에 기존에 잘 알려진 심장혈관계통 질환 위험인자들에서 유 의한차이가 있는 지를 관찰한 연구가 아니라, 두 군 모두 이미 급성 뇌졸중 환자이므로 다양한 심장혈관계통 질환 위험인자들에서 기 존 연구결과와 같이 통계적으로 유의한 차이를 보이기는 어려웠을 것으로 생각된다. 그럼에도 불구하고 연령에 비해 동맥경직도가 높 은 군에서 $\mathrm{HbAlc}$ 와 당뇨는 유의미한 차이를 보였고, 대부분 혈압 과 관련된 인자들 또한 높게 나타났다. PWV는 초기 동맥경화에 의 한 혈관의 변화를 예측할 수 있는 유용한 인자이며, 최근 여러 연구 를 통해 뇌졸중으로 입원한 환자들에서 PWV가 높을 경우 뇌졸중 의 재발 및 예후가 좋지 못하다는 결과가 보고되고 있다( $\mathrm{SeO}$ 등, 2008; $\mathrm{Kim}$ 등, 2011). 이러한 연구결과들을 고려해 볼 때, 뇌졸중 으로 입원한 환자들에게 당뇨와 관련된 여러 인자들을 관리하고, 입원 시 수축기혈압을 포함한 다양한 혈압관련 인자들을 조절하는 치료가 신속히 시행되고 효과를 얻을 수 있다면, 보다 적극적으로 $\mathrm{PWV}$ 를 정상범위로 조절하여 뇌졸중의 예후 및 재발률을 낮출 수 있는 하나의 적절한 치료법이 될 수 있음을 보여주는 근거로 의미 를 가진다고 생각된다.

본 연구는 몇 가지 한계점을 가지고 있다. 첫째, $\mathrm{PWV}$ 를 이용한 기존 연구들에서는 대상자의 수가 최소 500 명 이상이었다. 하지만
본 연구의 대상자는 상대적으로 작은 규모로 시행하여 비교적 결과 의 신빙성이 떨어질 우려가 있고, 기존에 잘 알려진 심혈관질환 위 험인자들과 통계적으로 유의한 차이를 발견하기 어려웠다. 둘째, 본 연구는 대상자의 $\mathrm{baPWV}$ 결과를 바탕으로 두 군으로 나누어 진 행하였다. 하지만 기존 선행 연구자들은 본 연구 방식으로 대상자 를 나누어 연구를 진행한 적이 없었기 때문에, 앞으로 더 많은 연구 를 통해 본 연구의 방식이 입증될 필요가 있으며, 그러한 연구들은 본 연구 결과의 신빙성을 높이는데 큰 도움이 될 것으로 생각된다. 이러한 한계점에도 불구하고, 본 연구 결과는 뇌졸중 환자의 재발 과 예후를 파악하고 치료하는데 도움이 될 수 있다는 점에서 의미 를 가질 수 있다.

Acknowledgements: I would like to thank Professor Ji Hoe Heo for providing me with valuable data for this thesis.

Funding: None

Conflict of interest: None

\section{References}

1. Blacher J, Asmar R, Djane S, London GM, safar ME. Aortic pulse wave velocity as a marker of cardiovascular risk in hypertensive patients. Hypertension. 1999, 33:1111-1117.

2. Boutouyrie P, Tropeano AI, Aamar R, Gautier I, Benetos A, Lacolley P, Laurent S. Aortic stiffness is an independent predictor of primary coronary events in hypertensive patients: A longitudinal study. Hypertension. 2002, 39:10-15.

3. Choi JC, Lee JS, Kang SY, Kang JH, Bae JM, Lee DH. Limitation of brachial-ankle pulse wave velocity in assessing the risk of stroke: Importance of instantaneous blood pressure. Cerebrovasc Dis. 2009, 27:417-425.

4. Expert Committee on the Diagnosis and Classification of Diabetes Mellitus. Report of the expert committee on the diagnosis and classification of diabetes mellitus. Diabetes Care. 2003, 26Suppl1:S5-20.

5. Expert Panel on Detection, Evaluation, and Treatment of High Blood Cholesterol in Adults. Executive Summary of The Third Report of The National Cholesterol Education Program (NCEP) Expert Panel on Detection, Evaluation, And Treatment of High Blood Cholesterol In Adults (Adult Treatment Panel III). JAMA. 2001, 285(19):2486-2497.

6. Franklin SS, Khan SA, Wong ND, Larson MG, Levy D. Is pulse pressure useful in predicting risk for coronary heart disease? The Framingham Heart Study. Circulation. 1999, 100:354-360.

7. Hamilton PK, Lockhart CJ, Quinn CE, McVeigh GE. Arterial stiffness: Clinical relevance, measurement and treatment. Clin Sci(Lond). 2011, 100:387-393.

8. Izzo JL. Arterial stiffness and the systolic hypertension syndrome. Curr Opin Cardiol. 2004, 19:341-352.

9. Jones DW, Hall JE. Seventh report of the Joint National 
Committee on Prevention, Detection, Evaluation, and Treatment of High Blood Pressure and evidence from new hypertension trials. Hypertension. 2004, 43(1):1-3.

10. Kim J, Cha MJ, Lee DH, Lee HS, Nam CM, Nam HS, et al. The association between cerebral atherosclerosis and arterial stiffness in acute ischemic stroke. Atherosclerosis. 2011, 219(2):887-891.

11. Laurent $S$, Boutouyrie P. Recent advances in arterial stiffness and wave reflection in human hypertension. Hypertension. 2007, 49:1210-1206.

12. Laurent S, Katsahian S, Fassot C, Tropeano AI, Gautier I, Laloux B, Boutouyrie P. Aortic stiffness is an independent predictor of fatal stroke in essential hypertension. Stroke. 2003, 34:1203-1206.

13. McLeod AL, Uren NG, Wilkinson IB. Non-invasive measures of pulse wave velocity correlate with coronary arterial plaque load in humans. J Hypertens. 2004, 22:363-368.

14. Motobe K, Tomiyama H, Koji Y, Yambe M, Gulinisa Z, Arai T, et al. Cut-off value of the ankle-brachial pressure index at which the accuracy of brachial-ankle pulse wave velocity measure- ment is diminished. Circulation journal : official journal of the Japanese Circulation Society. 2005, 69(1):55-60.

15. Rhee MY. Acute and chronic effects of smoking on the arterial wall properties and the hemodynamics in smokers with hypertension. Korean Circ J. 2005, 35:493-499.

16. Seo WK, Lee JM, Park MH, Park KW, Lee DH. Cerebral microbleeds are independently associated with arterial stiffness in stroke patients. Cerebrovasc Dis. 2008, 26(6):618-23.

17. Zieman SJ, Melenovsky V, Kass DA. Mechanisms, pathophysiology, and therapy of arterial stiffness. Arterioscler Thromb Vasc Biol. 2005, 25:932-943.

18. Park JS, Seo JJ, Chung JW, Cho HJ, Bae JW, Kim KI, et al. Association of the Invasively Measured Aortic Stiffness and Coronary Artery Disease. Korean Circulation J2005, 35:766-772.

19. Zo JH, Lee SK, Kim SH, Kim MA. The Relationship of Pulse-wave Velocity with Carotid Intima-media Thickness and Carotid Artery Distensibility. J Cardiovasc UItrasound 2006, 14(3):92-97. 